\title{
DEVELOPMENT OF ECOLOGICAL DENIM BLEACHING METHODS
}

\author{
DOI: $10.35530 /$ TT.2021.07
}

\author{
I. İvedi ${ }^{1 *}$, K. Yağcı², E. Tağaç²
}

\author{
${ }^{1}$ R\&D Department, Roteks Tekstil İhr. San. Ve Tic. A.Ş., Turkey \\ (E-mail: ismailivedi@roteks.com.tr) \\ ${ }^{2}$ Washing Department, Roteks Tekstil İhr. San. Ve Tic. A.Ş., Turkey \\ (E-mail: korhanyagci@roteks.com.tr, edaozgen@roteks.com.tr)
}

\begin{abstract}
Although the textile industry has many products to offer to humanity, it consumes a lot of energy and indirectly causes greenhouse gas emissions. With increasing environmental awareness, parameters such as the cost and performance of each industrial activity to society, as well as the use of natural resources and the possibility of causing global environmental problems to have become more frequently considered factors. In the denim bleaching process, the desired effect is usually obtained with the help of sodium hypochlorite. Sodium metabisulfite is then used for the neutralization process. Since these processes are carried out at high liquor ratios, the waste load resulting from the consumption of necessary chemicals and water is also high.

In this study, ecological bleaching methods have been developed as an alternative to the conventional sodium hypochlorite bleaching method by reducing the use of water and chemicals with low liquor and spraying bleaching methods. Denim garments subjected to bleaching with low liquor and spraying methods were compared with denim garments applied to sodium hypochlorite bleaching in industrial washing machines according to exhaustion method. In the spraying method, the mixture coming out of the narrow nozzle is mixed with the compressed air by means of a specially designed spray gun and sprayed in very small droplets. Thus, a good atomization is ensured, and a low liquor ratio water cloud is created.

The results between conventional and ecological bleaching processes were compared according to processes cost, water and chemical consumption, aging effect, tear strength, elasticity, and recovery analyses.
\end{abstract}

Keywords: bleaching, denim, low-liquor ratio, sustainability, spraying

\section{INTRODUCTION}

The concepts of sustainability, product life cycle and ecological production have become more and more important considering the dangers that may affect the entire ecosystem, such as global warming. Therefore, companies and consumers become more conscious day by day. According to a report published by the World Bank, the textile and fashion industry is the second most polluting world and responsible for $20 \%$ of the water consumed on our planet [1].

With the increase in greenhouse gas emissions and the risk of lack of water, many countries, companies, and organizations around the world have started to implement innovative initiatives and technologies in order to re-evaluate their activities and produce their products both using less water and causing low carbon emissions [2].

Textile is one of the basic human needs and almost all the textile fabrics are colored. Unfortunately, the extensive amounts of clean water, petrochemical based dyes, and chemicals are used for textile dyeing. After dyeing, these substances are discharged as pollutants. The disposal of this discharge is a serious issue which pollutes the natural 
environment. Therefore, there is a dire need to develop the novel dyeing processes with extremely low consumptions of water, dyes and chemicals [5].

Denim clothing has been deeply in people's favorite due to its easy and simple style. Along with the evolution of denim clothing, the self-characterized washing technique, for its production impose, has antique appearance and comfortable texture, which becomes the essential element leading to fashion [3]. In the production of denim garments, in order to create the desired aged effect on the products, whisker, laser, stone washing, spray, bleaching, etc. processes are implemented which are called dry and wet processes [4]. Among various methods, sodium hypochlorite oxidation method (chlorine bleaching), with its supreme efficiency, apply into the further area in industrial production [3].

In denim bleaching process a strong oxidative bleaching agent such as sodium hypochlorite or potassium permanganate added during the washing with or without stone addition. Discoloration produced is usually more apparent depending on strength of the bleach liquor quantity, temperature and treatment time. It is preferable to have strong bleach with short treatment time. Neutralization process should be taken for the bleached goods so that they should be adequately antichlored or after washed with peroxide to minimize yellowing [6]. The effect of enzyme wash using cellulase enzyme on the properties of denim garments to develop novel design and fashion. Three parameters in enzyme washing namely concentration of enzyme, washing temperature and time at $\mathrm{pH} 5.5$ were considered. They were chosed indigo dyed cotton denim garments (trousers) to investigate the optimum washing condition and processed by enzyme with the concentration of $0.5 \%$ to $3.5 \%$, temperature $40^{\circ} \mathrm{C}$ to $70^{\circ} \mathrm{C}$ and time $20 \mathrm{~min}$ to $60 \mathrm{~min}$ for the achievement with desired worn and aged effect. The effect of each parameter was discussed, and denim garments properties like tensile strength, elongation at break, weight loss, stiffness, water absorption, shrinkage, color fading and morphological values by SEM were evaluated. The optimized washing condition for the best value was found, $2 \%$ enzyme concentration at $55^{\circ} \mathrm{C}$ for $40 \mathrm{~min}$ [7].

The influences of the ultrasonic power, the processing time, temperature and sodium hypochlorite concentration on the bleaching-washing effect were analyzed based on the surface K/S value of denim fabric during the ultrasonic-assisted chlorine bleaching washing the denim. They were found that the ultrasonic collaborative sodium hypochlorite washing the denim with a better bleaching effect could save more energy than traditional stirring way. The optimum process followed as the ultrasonic power $400 \mathrm{w}$, the ultrasonic total times $20 \mathrm{~min}$, the bleaching temperature $25^{\circ} \mathrm{C}$ and the solution concentration $5 \%$ [8].

Jie $\mathrm{Xu}$ et al., were investigated the optimization methodology by combining ensemble of surrogates (ESs) with particle swarm optimization (PSO) to optimize production cost of chlorine bleaching for denim were proposed. The methodology starts from the data collections by conducting a Taguchi L25 (56) orthogonal experiment with the process variables and metrics for evaluating bleaching performances. Based on the data, they were separately constructed the quantitative relationships by using RBFNN, SVR, RF and ensemble of them. Then, accuracies of the surrogates were evaluated, and it was proved that the ESs outperforms the others. The ESs PSO approach shows great capability of optimizing production cost of sodium hypochlorite bleaching washing for denim [9].

In one article, the researchers studied nano bubble dyeing of cotton with 11 different reactive dyes. The fabric dyeing performance properties of shade depth, dry rubbing fastness, wet rubbing fastness, and washing fastness were assessed for the liquor ratio of 1:1. The performance of 1:1 dyeing was compared with the conventional dyeing having liquor ratios of 1:5 and 1:10 for the same dyes. All the 11 reactive dyes, dyed at liquor ratio of 1:1 exhibited the uniform dyeing, acceptable fastness properties, and superior air permeability along with zero liquid discharge in the main dyeing cycle [5]. 


\section{MATERIALS AND METHODS}

Indigo dyed denim fabric was purchased from Matesa Denim AŞ., Turkey. Weight of the fabric is $12 \mathrm{oz} / \mathrm{yd}^{2}$. It has a 3/1 Z twill weave structure, 99/1\% - CO/EL mixture and $24 \%$ elasticity. The amylase enzyme and dispersing agent for the desizing process were supplied from Dystar, Singapore. Sodium hypochlorite for bleaching process was purchased from Rubin Kimya AŞ., Turkey. Pumice stone for stonewash process was purchased from Kastone LTD., Turkey. Stonewash enzyme was purchased from Dystar, Singapore. Sodium metabisulfite used for neutralization was purchased from Akkim Kimya A.Ş., Turkey. Tolkar's 1326 liter model industrial washing machines were used for the conventional method and Y1lmak's 5000 liter Rainforest model was used for low liquor bleaching processes. The spraying machine was supplied from Method Makine, Turkey. The experimental scheme of the bleaching processes is shown in table 1 . The flow chart of each process is shown in figure 1.

Table 1. The experimental scheme of the bleaching processes

\begin{tabular}{|c|c|c|c|c|c|}
\hline Method & $\begin{array}{l}\text { Sample } \\
\text { quantity } \\
\text { (pants) }\end{array}$ & Liquor ratio (kg/lt) & Water (L) & $\begin{array}{l}\text { Temperature } \\
\left({ }^{\circ} \mathrm{C}\right)\end{array}$ & $\begin{array}{l}\text { Chemical } \\
\text { amount } \\
(\mathrm{g} / \mathrm{lt})\end{array}$ \\
\hline $\begin{array}{c}\text { Conventional } \\
\text { Exhaustion }\end{array}$ & 50 & $\begin{array}{c}1: 10 \text { (Bleach) } \\
\text { 1:7 (Neutralization) } \\
\text { 1:7 (Washing) } \\
\text { 1:7 (Washing) }\end{array}$ & $\begin{array}{c}250 \text { (Bleach) } \\
175 \text { (Neutralization) } \\
175 \text { (Washing) } \\
175 \text { (Washing) }\end{array}$ & $\begin{array}{l}50 \\
\text { Cold } \\
\text { Cold } \\
\text { Cold }\end{array}$ & $\begin{array}{c}12(\mathrm{NaOCl}) \\
4\left(\mathrm{Na}_{2} \mathrm{~S}_{2} \mathrm{O}_{5}\right) \\
-\end{array}$ \\
\hline $\begin{array}{l}\text { Low Liquor } \\
\text { Washing }\end{array}$ & 50 & $\begin{array}{c}1: 5 \text { (Bleaching) } \\
1: 3 \text { (Neutralization) } \\
1: 3 \text { (Washing) } \\
\text { 1:3 (Washing) }\end{array}$ & $\begin{array}{c}125 \text { (Bleaching) } \\
75 \text { (Neutralization) } \\
75 \text { (Washing) } \\
75 \text { (Washing) } \\
\end{array}$ & $\begin{array}{l}50 \\
\text { Cold } \\
\text { Cold } \\
\text { Cold }\end{array}$ & $\begin{array}{c}24(\mathrm{NaOCl}) \\
13 \\
\left(\mathrm{Na}_{2} \mathrm{~S}_{2} \mathrm{O}_{5}\right)\end{array}$ \\
\hline Spraying & 50 & $\begin{array}{c}\text { 1:0.24 (Bleaching) } \\
\text { 1:3 (Neutralization) } \\
\text { 1:3 (Washing) } \\
\text { 1:3 (Washing) }\end{array}$ & $\begin{array}{c}6 \text { (Bleaching) } \\
75 \text { (Neutralization) } \\
75 \text { (Washing) } \\
75 \text { (Washing) }\end{array}$ & $\begin{array}{l}\text { Cold } \\
\text { Cold } \\
\text { Cold } \\
\text { Cold }\end{array}$ & $\begin{array}{c}334\left(\mathrm{NaOCl}^{\mathrm{NaO}}\right) \\
3\left(\mathrm{Na}_{2} \mathrm{~S}_{2} \mathrm{O}_{5}\right) \\
- \\
-\end{array}$ \\
\hline
\end{tabular}

Firstly, denim pants were produced after cutting-sewing processes. Then, they were subjected to washing processes according to the experimental plan shown in Table 1 . In order to evaluate the differences between the application methods, the following tests were applied to the products:

- Elasticity and recovery analyses according to ASTM D3107-07 standard.

- Tear strength analysis according to ISO 13937-2:2000 standard.

- $\quad$ Light cabinet analysis to evaluate the aging effect according to ISO 3664:2009 standard.

- Wasteload of bleaching methods analysed and compared each other.

Wastewater analyzes of ecological and conventional processes carried out in Çevtest Ölçüm Laboratuvarı Tic. Ltd., a laboratory accredited by TÜRKAK according to AB-0091T and TS EN ISO/IEC 17025:2017 standard. Only conventional and low liquor methods have been analyzed since almost no wastewater is generated in the spraying method. In addition to these analyses, process cost, water and chemical consumption were calculated and compared each other. Table 2 includes wastewater measurement parameters and standards. 


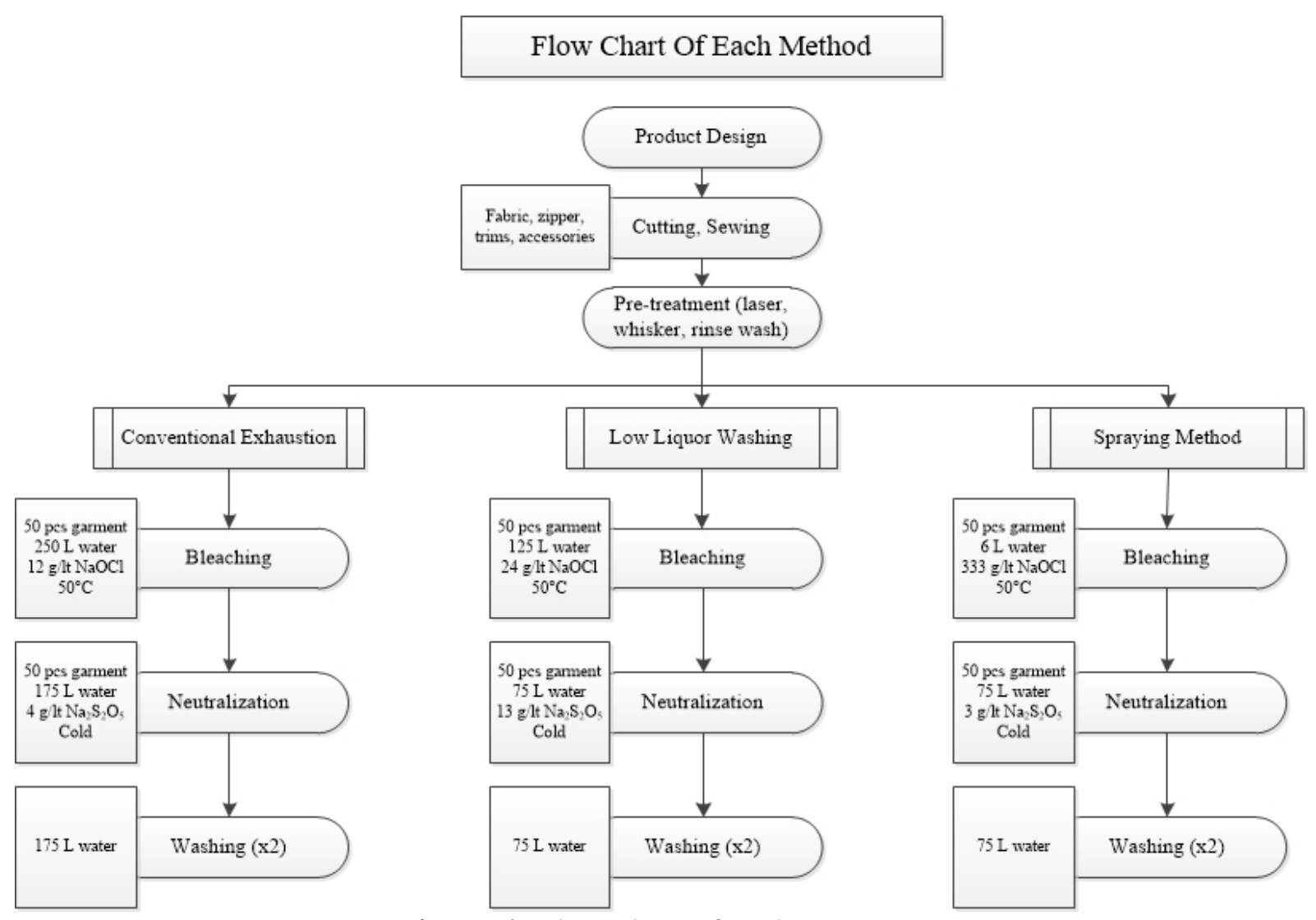

Figure 1. Flow chart of each process

Table 2. Wastewater measurement parameters and standards

\begin{tabular}{|c|c|c|}
\hline Parameter & Unit & Standard \\
\hline Chemical Oxygen Demand (COD) & $\mathrm{mg} / \mathrm{lt}$ & SM 5520-B \\
\hline Free Chlorine & $\mathrm{mg} / \mathrm{lt}$ & $\mathrm{SM} 4500-\mathrm{CI} \mathrm{G}$ \\
\hline Biochemical Oxygen Demand (BOD) & $\mathrm{mg} / \mathrm{lt}$ & $\mathrm{SM} 5210 \mathrm{~B}$ \\
\hline Ammonium Nitrogen & $\mathrm{mg} / \mathrm{lt}$ & $\mathrm{SM} 4500-\mathrm{NH}_{3} \mathrm{~B}, \mathrm{~F}$ \\
\hline Suspended Solids & $\mathrm{mg} / \mathrm{lt}$ & $\mathrm{SM} 2540 \mathrm{D}$ \\
\hline Conductivity & $\mu \mathrm{S} / \mathrm{cm}$ & $\mathrm{SM} 2520 \mathrm{~B}$ \\
\hline $\mathrm{pH}$ & - & $\mathrm{SM} 4500 \mathrm{H} \mathrm{B}$ \\
\hline
\end{tabular}

\section{RESULTS AND DISCUSSIONS}

When the results are examined, for the aging effect, although less water is used in the low liquor process compared to the conventional method, a similar effect was obtained in a shorter time. In addition, the homogeneity between the products is within acceptable limits. As it can be seen in figure 2, more vivid and moire effects were obtained in the spraying method. Table 3 shows the elasticity and tear strength analysis results of the conventional methods with alternative ecological bleaching processes. 


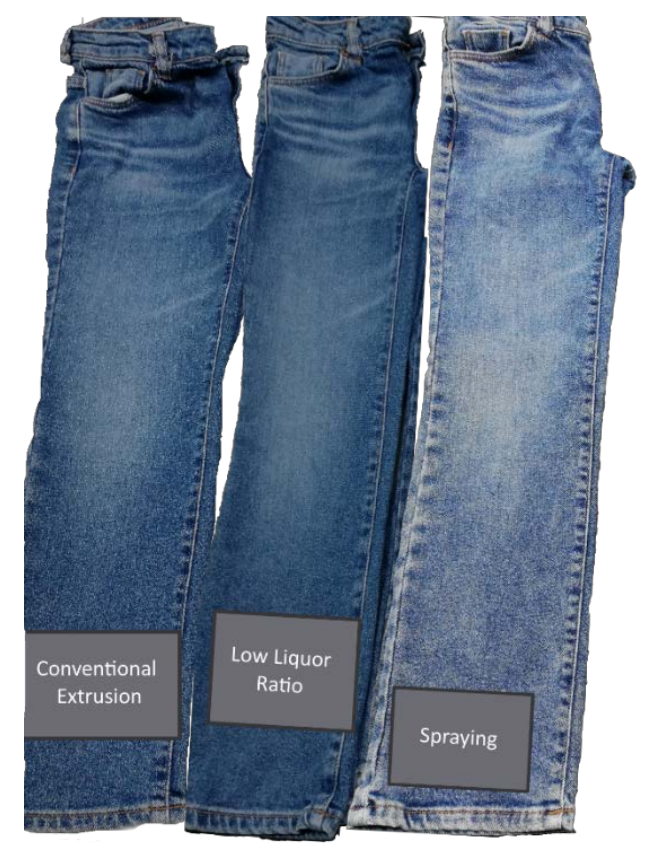

Figure 2. Bleaching methods

Table 3. Tear strength, elasticity and recovery analyse results

\begin{tabular}{|c|c|c|c|c|}
\hline \multirow{2}{*}{ Bleaching Method } & \multicolumn{2}{|c|}{ Tear strength (N) } & Elasticity & $\begin{array}{c}\text { Recovery } \\
\text { (\%) }\end{array}$ \\
\cline { 2 - 4 } $\begin{array}{c}\text { Raw Samples (non- } \\
\text { bleached) }\end{array}$ & 35.74 & 41.84 & 18.44 & 4 \\
\hline Conventional Exhaustion & 29.16 & 29.46 & 21.94 & 12 \\
\hline Low Liquor Ratio & 22.58 & 30.23 & 18.57 & 6 \\
\hline Spraying & 23.45 & 26.49 & 19.92 & 9 \\
\hline
\end{tabular}

No statistically significant difference was observed between the results of elasticity and tear strength analysis. All samples have tear strength above the limits $(15 \mathrm{~N})$ determined according to the ISO 13937-2:2000 standard. Exposure of fabrics to chemical, heat and mechanical forces caused a loss of strength as expected. Considering the results of the elastic recovery analysis, it was measured as raw samples, low liquor, spraying and conventional method, in descending order. The highest water consumption is realized in the conventional method with the amount of 31 liters $/ \mathrm{kg}$ of product. The least water consumption was achieved in the spraying method with 9 liters/kg of product. Chemical usage per product was occurred as spraying method, conventional and low liquor ratio, in ascending order, respectively. Although the waste load seems to have been realized at the least in the conventional method, the reason for this seems to have decreased proportionally as more water is used in the conventional method. Figure 3 shows the comparison of water, chemical and waste loads. 


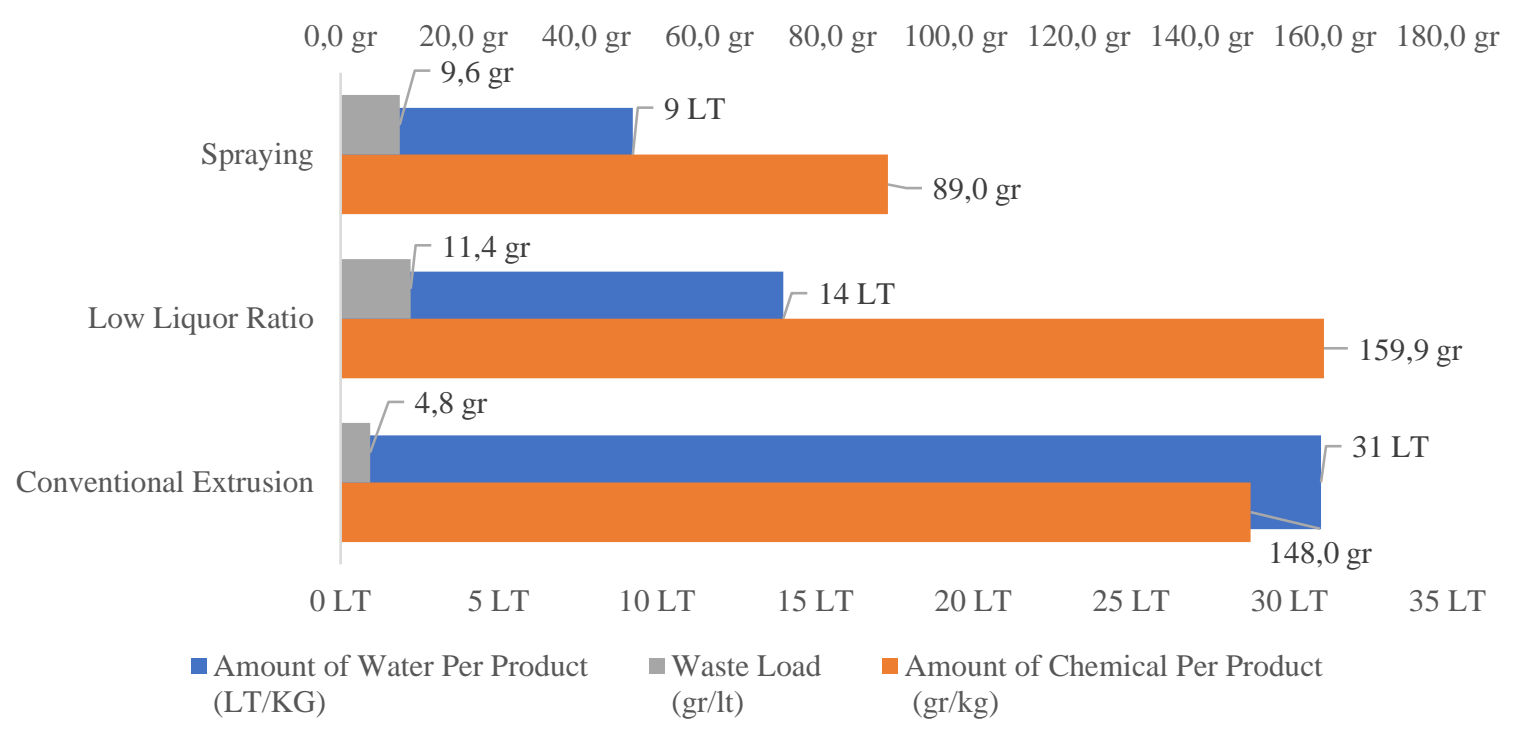

Figure 3. Amount of water, chemical and waste load

When the process costs are compared, it is seen that the spraying method is $30 \%$ lower and the low liquor method is $20 \%$ lower than the conventional method. Wastewater analysis results are shown in table 4.

Table 4. Wastewater analysis results

\begin{tabular}{|l|c|c|c|c|c|c|}
\hline \multirow{2}{*}{ Parameter } & $\begin{array}{c}\text { Low liquor } \\
\text { method }\end{array}$ & $\begin{array}{c}\text { Conventional } \\
\text { exhaustion }\end{array}$ & $\begin{array}{c}\text { Low liquor } \\
\text { method }\end{array}$ & $\begin{array}{c}\text { Conventional } \\
\text { exhaustion }\end{array}$ & \multirow{2}{*}{ Standard } \\
\cline { 2 - 5 } & \multicolumn{2}{|c|}{ Value (total) } & \multicolumn{2}{|c|}{ Value (per kg.product) } & \\
\hline $\begin{array}{l}\text { Chemical Oxygen } \\
\text { Demand (COD) }\end{array}$ & $323.80 \mathrm{mg} / \mathrm{lt}$ & $294.70 \mathrm{mg} / \mathrm{lt}$ & $2.89 \mathrm{mg} / \mathrm{lt}$ & $5.36 \mathrm{mg} / \mathrm{lt}$ & $\mathrm{TS} 2789$ \\
\hline Free Chlorine & $28.10 \mathrm{mg} / \mathrm{lt}$ & $1.87 \mathrm{mg} / \mathrm{lt}$ & $0.25 \mathrm{mg} / \mathrm{lt}$ & $0.03 \mathrm{mg} / \mathrm{lt}$ & $\begin{array}{c}\mathrm{SM} 4500- \\
\mathrm{Cl} \mathrm{G}\end{array}$ \\
\hline $\begin{array}{l}\text { Biochemical Oxygen } \\
\text { Demand (BOD) }\end{array}$ & $64.40 \mathrm{mg} / \mathrm{lt}$ & $56.40 \mathrm{mg} / \mathrm{lt}$ & $0.58 \mathrm{mg} / \mathrm{lt}$ & $1.03 \mathrm{mg} / \mathrm{lt}$ & $\mathrm{SM} 5210 \mathrm{~B}$ \\
\hline Ammonium Nitrogen & $0.81 \mathrm{mg} / \mathrm{lt}$ & $15.67 \mathrm{mg} / \mathrm{lt}$ & $0.01 \mathrm{mg} / \mathrm{lt}$ & $0.28 \mathrm{mg} / \mathrm{lt}$ & $\begin{array}{c}\mathrm{SM} 4500- \\
\mathrm{NH} \mathrm{H}_{3} \mathrm{~B}, \mathrm{~F}\end{array}$ \\
\hline Suspended Solids & $1951.00 \mathrm{mg} / \mathrm{lt}$ & $5334.00 \mathrm{mg} / \mathrm{lt}$ & $17.42 \mathrm{mg} / \mathrm{lt}$ & $96.98 \mathrm{mg} / \mathrm{lt}$ & $\mathrm{SM} 2540 \mathrm{D}$ \\
\hline Conductivity & $2900 \mu \mathrm{S} / \mathrm{cm}$ & $6780 \mu \mathrm{S} / \mathrm{cm}$ & $25.89 \mathrm{mg} / \mathrm{lt}$ & $123.27 \mathrm{mg} / \mathrm{lt}$ & $\mathrm{SM} 2520 \mathrm{~B}$ \\
\hline pH & $8.57 / 23.2^{\circ} \mathrm{C}$ & $7.96 / 23.2^{\circ} \mathrm{C}$ & $8.57 / 23.2^{\circ} \mathrm{C}$ & $7.96 / 23.2^{\circ} \mathrm{C}$ & $\begin{array}{c}\mathrm{SM} 4500 \\
\mathrm{H}+\mathrm{B}\end{array}$ \\
\hline
\end{tabular}

When the results are examined, although the $\mathrm{pH}$ difference is not much, the difference can be explained by the amount of sodium hypochlorite used in the boiler with the same liquor ratio. When the sodium hypochlorite usage rates of low liquor ratio and conventional exhaustion processes are examined, it is seen that more sodium hypochlorite per liter is used in conventional exhaustion. COD-BOD ratios appear slightly higher in the low liquor trial. However, per kg, it is seen that low liquor method has more advantageous. The difference in conductivity - suspended solids - ammonium nitrogen is due to the high amount of sodium hypochlorite given per liter. Therefore, these values were higher in conventional exhaustion method. 


\section{CONCLUSIONS}

In this study, denim fabrics with 3/1 twill weave structure containing 99/1\% cotton/elastane were carried out in bleaching processes by conventional, low liquor and spraying methods after cutting-making processes. The results were compared in terms of aging effect, physical properties of the fabric such as elasticity, tear strength etc., waste load, water and chemical consumption, and process cost.

When the results were examined, the aging effect closest to the conventional method was obtained with the low liquor method. No statistically significant difference was observed between the results of elasticity and tear strength analysis. All samples have tear strength above the limits (15 N) determined according to the ISO 13937-2:2000 standard. Considering the results of the elastic recovery analysis, it was measured as low liquor, spraying and conventional method, in descending order. A similar effect has been developed in a shorter time compared to the conventional method, without affecting the physical properties of the product, with a $20 \%$ lower cost.

The highest water consumption is realized in the conventional method with the amount of 31 liters $/ \mathrm{kg}$ of product. Compared to the conventional method, the water consumption was reduced by $69.3 \%$ and chemical consumption by $39.8 \%$ with the spraying method. Thus, approximately 88 million liters of water and 5.92 million $\mathrm{kg}$ of chemicals were saved for a company that produces an average of 8 million denim pants per year.

\section{ACKNOWLEDGEMENTS}

The authors would like to express appreciation for the support of the The Scientific and Technological Research Council of Turkey [Project Number $=3180537$ ].

\section{REFERENCES}

[1] Kant, R., Textile Dyeing Industry an Environmental Hazard, In: Natural Science, 2012, 4, 1

[2] Pekin, M., Soruşbay, C., Greenhouse Gas Emissions Produced By Transportation Sector, In: Thesis (M.Sc.), İstanbul Technical University, Institute of Science and Technology, 2006

[3] Li, S., et al., Optimization of Chlorine Bleaching Parameters for Indigo Denim Textile Based on the Model of Response Surface Model and Genetic Algorithm, In: Journal of Physics: Conference Series, IOP Publishing, 2020, 012026

[4] Arjun, D., et al., Technology of industrial denim washing, In: International Journal of Industrial Engineering \& Technology, 2013, 3, 4, 25-34

[5] Mohsin, M., et al., Novel, sustainable and water efficient nano bubble dyeing of cotton fabric, Cellulose, 2020, 27, 10, 6055-6064

[6] Arjun, D., Hiranmayee, J., Farheen, M.N., Technology of industrial denim washing, International Journal of Industrial Engineering \& Technology, 2013, 3, 4, 25-34

[7] Haq, U.N., Khan, M.M.R., Investigation of the bulk, surface and transfer properties of chlorine bleached denim apparel at different condition, European Scientific Journal, 2015, 11, 12

[8] Shi, W.Q., et al., Study on chlorine bleaching-washing of denim fabric under ultrasonic conditions, In: Key Engineering Materials. Trans Tech Publications Ltd, 2016, 202-209

[9] $\mathrm{Xu}$, J., et al., Cost optimization of sodium hypochlorite bleaching washing for denim by combining ensemble of surrogates with particle swarm optimization, Journal of Engineered Fibers and Fabrics, 2021, 16, 15589250211022331 